Spanish-Language Newspapers in the United States

\author{
Author(s): Robert B. Kent and Maura E. Huntz
}

Source: Geographical Review, Jul., 1996, Vol. 86, No. 3, Latin American Geography (Jul., 1996), pp. 446-456

Published by: Taylor \& Francis, Ltd.

Stable URL: https://www.jstor.org/stable/215508

JSTOR is a not-for-profit service that helps scholars, researchers, and students discover, use, and build upon a wide range of content in a trusted digital archive. We use information technology and tools to increase productivity and facilitate new forms of scholarship. For more information about JSTOR, please contact support@jstor.org.

Your use of the JSTOR archive indicates your acceptance of the Terms \& Conditions of Use, available at https://about.jstor.org/terms 


\section{SPANISH-LANGUAGE NEWSPAPERS IN THE UNITED STATES}

\section{ROBERT B. KENT and MAURA E. HUNTZ}

$\mathcal{T}_{\text {h }}$ ing only their native language. When population concentrations who spoke the same language arose, foreign-language newspapers often appeared to serve them. Typically, these newspapers terminated publication once the group gained command of the English language and when the influx of additional group members in the area subsided (Fishman 1966; Monmonier 1986; Emery and Emery 1988).

The Spanish-language press, however, is different from other foreign-language publications. Spanish-language newspapers were published in New Orleans as early as 1808 , and their presence in the Southwest predated the United States' territorial acquisition in the wake of the 1848 Mexican-American War. Over the following decades the Spanish-language press prospered in the Southwest, for the continuing influx of Mexican immigrants provided the critical impetus. By 1900 the first Spanishlanguage newspapers had appeared in the East. In 1990 Spanish-language newspapers in Chicago, New York, and Miami were commonplace. The historical and journalistic development of the Spanish-language press and Latin American national-origin presses and newspapers has been documented by historians and journalists for the United States and several of its regions. No attempt has been made to examine the historical geography of Spanish-language newspaper publication, however.

In this note we fill that void. We focus on a series of maps that correspond to the periods 1848-1876, 1877-1899, 1900-1929, 1930-1959, and 1960-1992. These periods reflect, to some degree, historical events and immigration trends related to the Spanish-speaking population of the United States: the end of the MexicanAmerican War, the signing of the Treaty of Guadalupe Hidalgo, and the annexation of nearly half of Mexico in 1848; the conclusion of the Spanish-American War and the subsequent annexation of Puerto Rico in 1898; the beginning of the Great Depression in 1929 and the later repatriation of thousands of Mexican nationals to Mexico; and the Cuban Revolution in 1959 and the subsequent migration of thousands of Cubans to the United States. The maps portray the regional patterns of newspaper establishment for the 582 Spanish-language newspapers-including daily, weekly, monthly, and irregularly issued newspapers-published in the United States since 1848. Only the location and the time period during which they were founded are portrayed; no distinctions are made for frequency of publication. In fact, however, weeklies have dominated, representing 62 percent of all Spanishlanguage newspapers; the balance is divided among those irregularly issued, 26 percent; dailies, 7 percent; and monthlies, 5 percent. Our study is limited to the states and territories of the continental United States.

4 DR. KENT is a professor of geography and planning at the University of Akron, Akron, Ohio 44325-5005. Ms. HuNTz is a technical training manager in the Commercial Systems Group, Trimble Navigation, Sunnyvale, California 94086. 


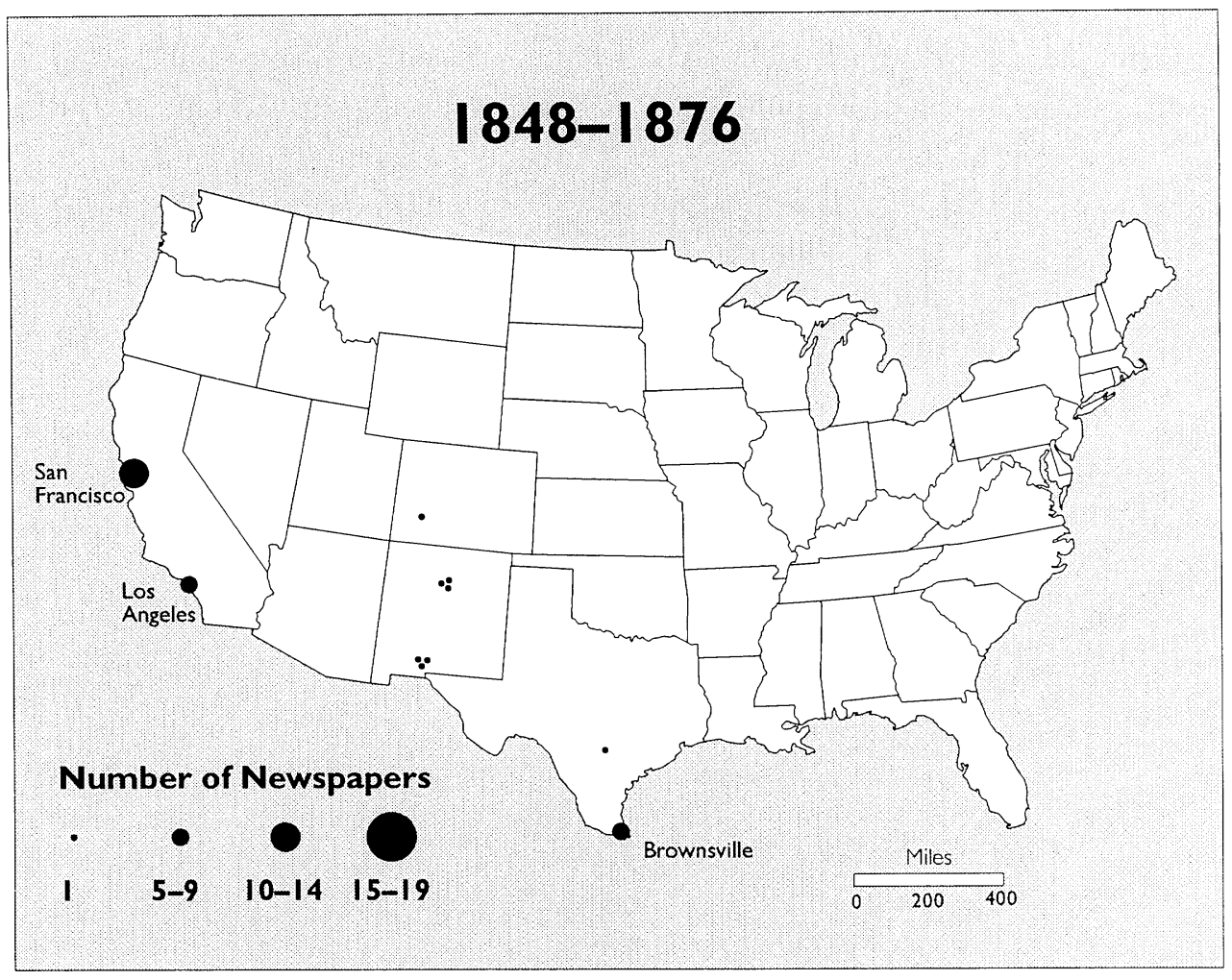

FIG. 1-Spanish-language newspapers established between 1848 and 1876 . (Cartography by the Laboratory for Cartographic and Spatial Analysis, University of Akron)

The data are drawn from a variety of sources. The bibliographies of the Mexican American press published by Rios and Castillo $(1970 ; 1972)$ provided critical data on the Spanish-language press in the Southwest. In addition, we used standard printmedia reference sources, notably N.W. Ayer and Sons Directory of Newspapers and Periodicals (1933-1992); Editor and Publisher International Yearbook (1959-1992); Encyclopedia Directory of Ethnic Newspapers and Periodicals in the United States (1976); and Hispanic Media and Markets (1988-1992).

\section{Early Development in the Southwest, 1848-1876}

Three initial regional concentrations of Spanish-language newspapers can be identified-California, the Upper Rio Grande Valley, and South Texas (Figure 1). All three were territories gained in 1848 , and much of the population was Mexican or Hispano. Thirty-one newspapers were founded during this period, but no more than ten were ever published in any given year.

San Francisco was the center for Spanish-language publishing between 1848 and 1876, for ten newspapers were published there. El Eco del Pacifico, a daily, was published for five years during the mid-1850s, and in the latter part of the 1860 s as many 


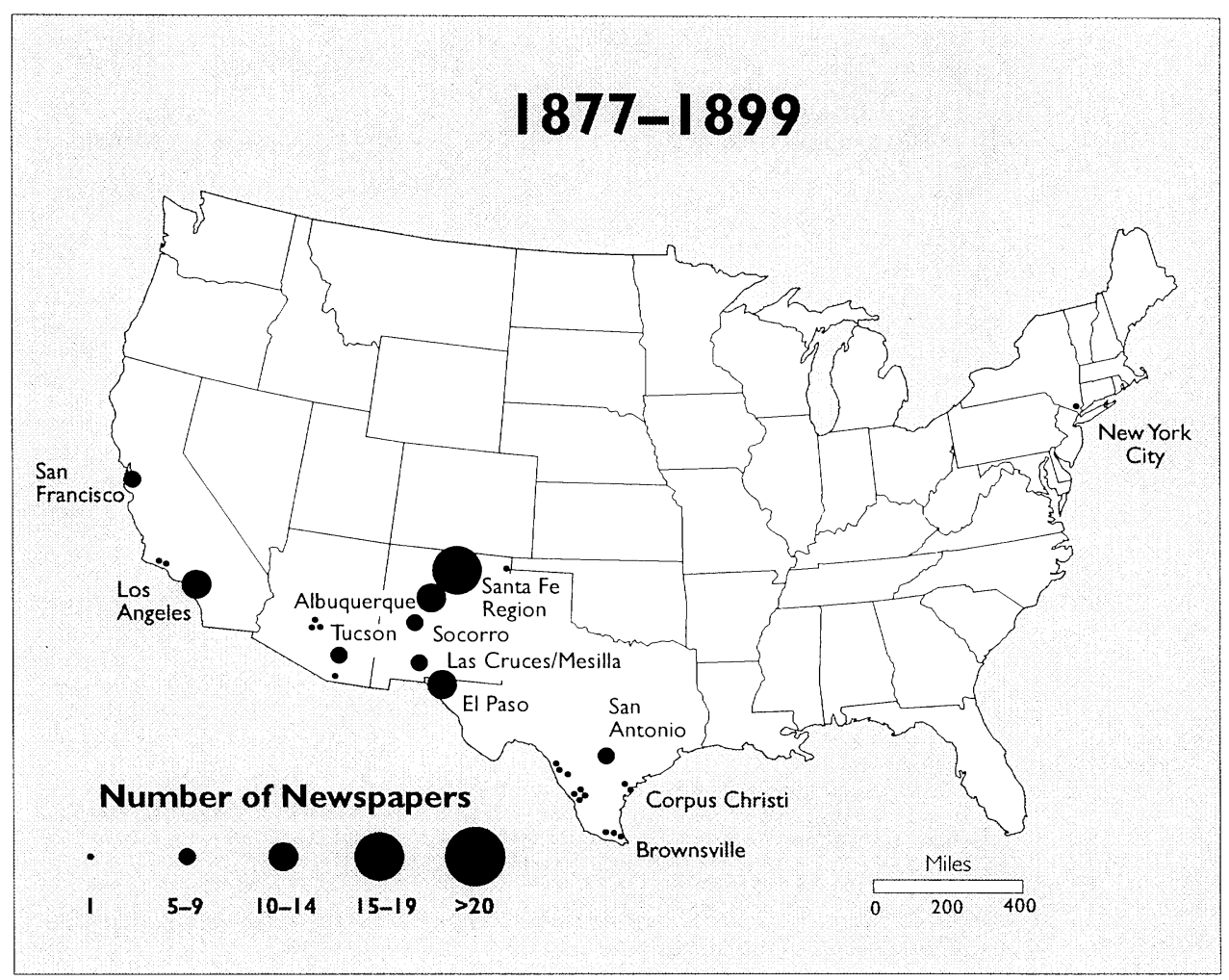

Fig. 2-Spanish-language newspapers established between 1877 and 1899. (Cartography by the Laboratory for Cartographic and Spatial Analysis, University of Akron)

as five Spanish-language newspapers circulated in the city. Brownsville, Texas, represented a significant center as well, with seven Spanish-language newspapers published during this period, including both dailies and weeklies. La Bandera, a weekly, was published for fifteen years-1848-1863-and in the mid-1860s four newspapers were published in Brownsville. Los Angeles, Santa Fe, and Las Cruces also boasted Spanish-language newspapers, some of which-notably El Nuevo Mexicano (18621958) and El Boletín Popular (1872-1910), each in Santa Fe-were published well into the 1900 .

\section{A Hispano CoRe, $1877-1899$}

The years between 1877 and 1899 marked a period of growth and geographical concentration of Spanish-language newspapers (Figure 2). The Upper Rio Grande Valley-a region extending from El Paso, Texas through Santa Fe and as far north as Taos, New Mexico-experienced the greatest growth, with the founding of a total of fiftythree newspapers during the period. The pattern reflects the traditional presence of Hispanos along the Upper Rio Grande and the numerous Mexicans who entered the United States to work as migrant farmworkers, as laborers, or in railroad construction (Carlson 1990; Nostrand 1992). Most of these newspapers were weekly publica- 
tions, although one daily, La Voz del Pueblo, in Las Vegas, New Mexico, lasted for thirty-six years (1889-1925). Many a weekly newspaper was published continually for decades-El Tiempo in Las Cruces (1882-1913), El Taoseño in Taos (1887-1948), El Independiente in Albuquerque (1894-1979), El Labrador in Las Cruces (1896-1942), and El Combate in Socorro (1898-1959). Although bilingual publication occurred frequently in the Upper Rio Grande Valley, the practice was rare in other parts of the United States.

California continued as a secondary focus of Spanish-language newspaper publication in this period, as did southern Texas, and southern Arizona appeared for the first time. In California, Los Angeles represented the principal node, with a total of eleven newspapers published there. Weekly newspapers with short publication histories-one to two years-dominated. One notable exception was El Monitor Mexicano, which was published weekly for twenty-one years (1890-1911). Tucson emerged for the first time as a focus for Spanish-language newspapers in the Southwest. Fewer newspapers-only six-were published there than in Los Angeles, but these were distinguished from the Los Angeles newspapers by their longevity. El Fronterizo appeared weekly for more than forty years (1878-1929), and La Alianza remained in weekly circulation for nearly eighty years (1886-1965). Spanishlanguage newspaper publication in South Texas continued, with new newspapers cropping up in several border cities as well as in San Antonio.

A harbinger also occurred during this period. Greater New York City registered its first Spanish-language newspaper, La Patria (1892-1898). Thus the first Spanishlanguage newspaper on the East Coast was born, largely as a result of the immigration of Cubans to the New York area.

\section{Development Reaches an Early Peak, 1900-1929}

The Spanish-language press remained concentrated in California, the Upper Rio Grande Valley, and South Texas during the early decades of the twentieth century (Figure 3). Mexican immigration, fueled in part by the expanding employment opportunities in Southwestern agriculture and construction and by the Mexican Revolution (1910-1920), numbered three-quarters of a million in the thirty-year period. In California, growth centered primarily in Los Angeles and secondarily in San Francisco, with a scattering of newspapers founded in cities along the United StatesMexico border-specifically in San Diego and Calexico. As in the last quarter of the nineteenth century, the Upper Rio Grande Valley represented the greatest concentration of new Spanish-language newspapers. El Paso, Las Cruces, Albuquerque, and the region around Sante Fe each saw between ten and twenty new newspapers during these years. South Texas and the borderlands also experienced sizable concentrations: More than twenty newspapers were established in San Antonio, more than fifteen in Brownsville, between five and nine in Corpus Christi and Del Rio, and a few in several border towns along the lower Rio Grande.

Outliers from the traditional core regions began to appear in the early 1900 s as Spanish-speaking immigrants moved beyond the border states. A weekly newspa- 


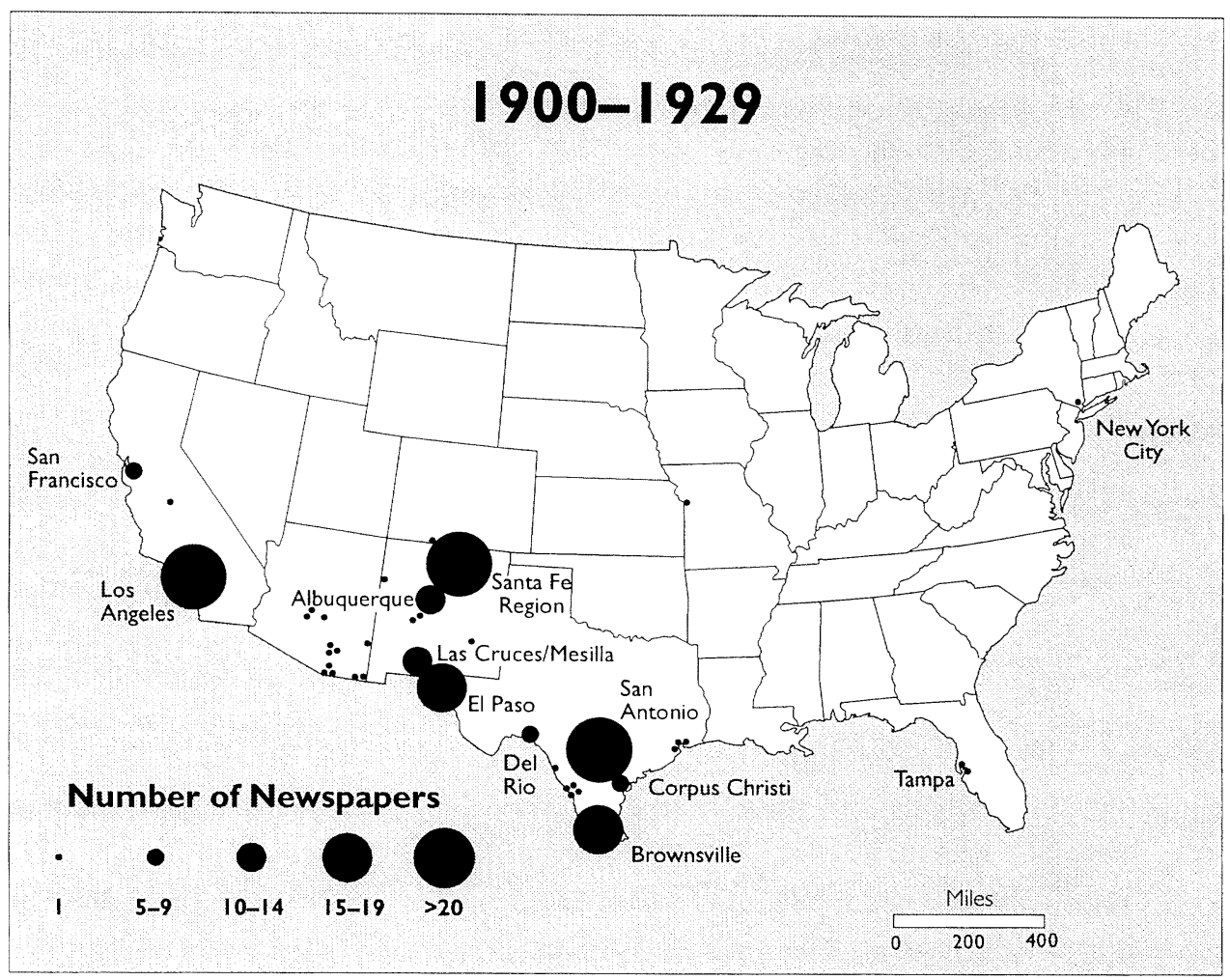

Fig. 3-Spanish-language newspapers established between 1900 and 1929. (Cartography by the Laboratory for Cartographic and Spatial Analysis, University of Akron)

per, El Cosmopolita, was published in Kansas City for nearly five years (1914-1919). On the East Coast, one Spanish-language daily, El Diario-La Opinión, began publication in 1913 in New York City as both Cuban and Puerto Rican immigrants started to arrive in appreciable numbers. The newspaper continues in print today, with a professional staff of more than forty and a daily circulation that exceeds 60,000 . In Florida, the cigar industry in Tampa that was initiated by Cuban expatriates and employed Cuban immigrants led to the establishment of two weekly newspapers, $\mathrm{La}$ Traducción-Prensa (1901-1966) and La Gaceta (1922-1992).

Spanish-language newspapers increased to all-time high numbers between 1900 and 1929. In this thirty-year period a total of 218 were founded-more than one-third of all Spanish-language newspapers established between 1848 and 1992. Not only did the number of newspapers founded grow during this period, but dailies became more common-a total of eighteen. Established in border areas with a history of Spanish-language newspaper publication, some remained for long periods: $\mathrm{La}$ Prensa in San Antonio (1913-1963); El Paso del Norte (1904-1918), La República (1917-1929), La Patria (1919-1924), and El Continental (1929-1992), all in El Paso; and La Opinión (1926 to the present) in Los Angeles. In the traditional Hispano regions 


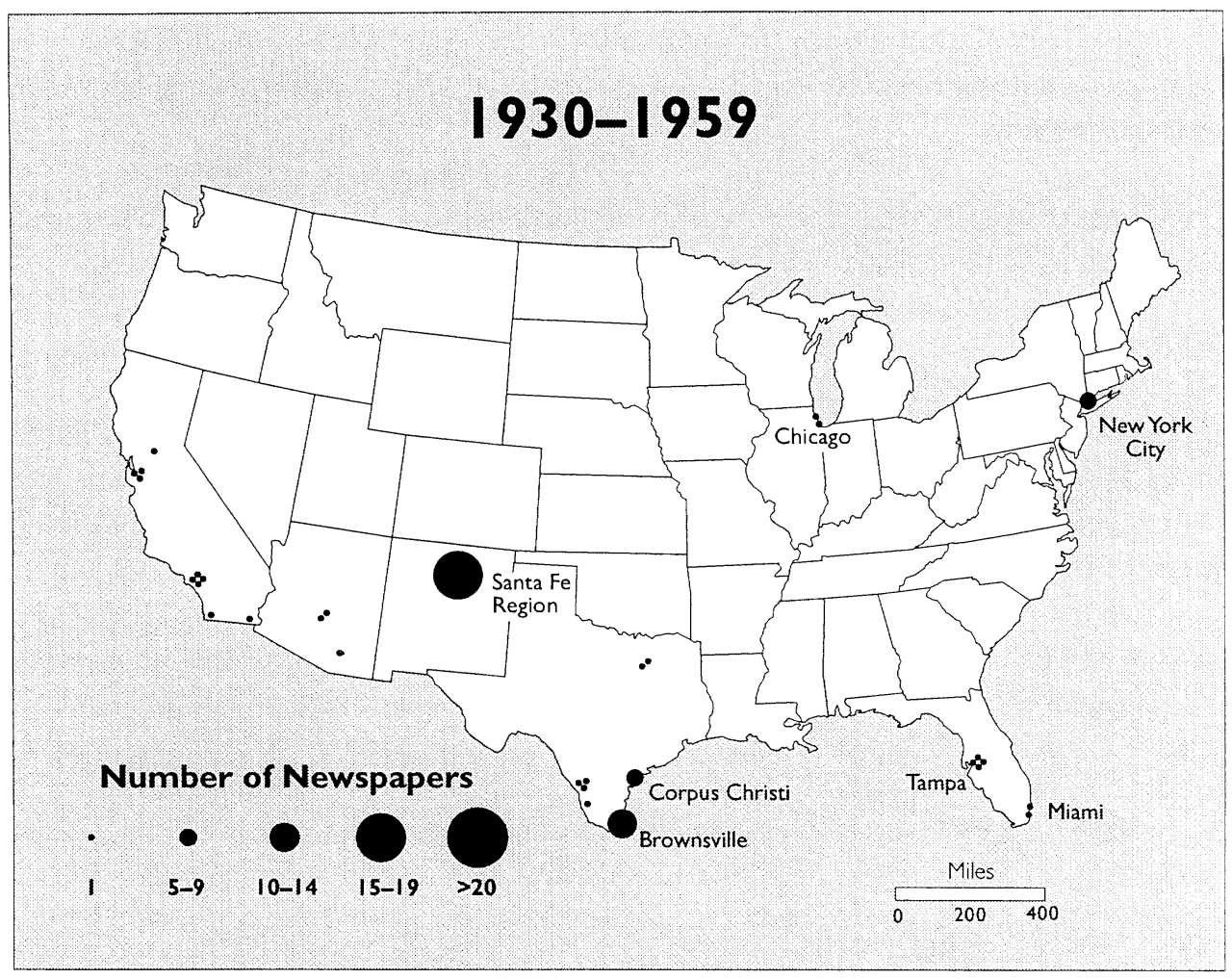

Fig. 4-Spanish-language newspapers established between 1930 and 1959. (Cartography by the Laboratory for Cartographic and Spatial Analysis, University of Akron)

of the Upper Rio Grande Valley, weeklies with comparatively short publication histories dominated. Nevertheless, some were published for decades, including the $R e$ vista Popular in Taos (1900-1936), El Defensor del Pueblo in Socorro (1904-1953), La Voz del Río Grande in Española (1909-1951), the Hispano-Americano in Belen (1911-1949), and La Estrella in Las Cruces (1911-1936).

\section{The Depression, Decline, ANd New Growth, 1930-1959}

Two distinct geographical patterns of Spanish-language newspaper founding characterize the era between the Great Depression and the post-World War II years (Figure 4). West of the Mississippi River the rate of new newspaper publication slowed markedly. The Depression diminished employment opportunities in the Southwest for Mexican immigrants, while the repatriation of large numbers of Mexican nationals and strict immigration quotas diminished the demand for new Spanishlanguage newspapers. The Bracero Program, initiated in 1943 to relieve labor shortages caused by World War II, brought many Mexicans back to the United States in subsequent years and mitigated some of the return migration of the Depression years. Nevertheless, only a few newspapers were founded in California and Arizona, and no new ones appeared in El Paso or Las Cruces. The ongoing strength of the tra- 
ditional Hispano population and culture in Santa Fe and the Rio Arriba country of southern Colorado is evidenced by a continuation of new Spanish-language newspapers there.

Perhaps more significant was the increasing appearance of Spanish-language newspapers in the states east of the Mississippi. Seventeen newspapers were founded in the East during these years. In contrast to the western states, where most newspapers were established in small or medium-sized cities and towns, in the East almost all of them were founded in urban centers-Chicago, New York, Miami, and Tampa. Greater New York City showed a significant increase in Spanish-language newspapers during this period, with eight new ones. These were mostly weeklies, but El Diario de Nueva York, a daily founded in 1948, was an important exception. The expansion resulted largely from the migration of Puerto Ricans to the mainland, particularly to New York.

Florida also experienced notable growth, with four newspapers in Tampa and two in Miami. All of the Tampa newspapers were weeklies, and most of them were short-lived-the Ybor City Sunday Times remained in publication the longest (1950-1955). The most significant of these Florida newspapers was Diario Las Américas (1953 to the present), a Miami daily. Few Spanish speakers resided in Miami in 1953, but Horacio Aguirre, the newspaper's founder, believed that the city's strategic geographical location would make it a gateway to the Americas (Veciana-Suarez 1987). His predictions have been more than validated: In 1997 nearly 70,000 copies of Diario Las Américas circulate daily in the greater Miami area, and an electronic edition of the newspaper is available daily on the World Wide Web (http://www. diariolasamericas.com).

Three Spanish-language newspapers appeared in Chicago to serve the growing Mexican and Mexican American population attracted there by manufacturing jobs and meat packing (Puerto Rican migrants were an important secondary market). El Nacional and Adelanto Bienestar Cultural, weeklies, had short publication histories (1933-1936 and 1944-1950, respectively).

Generally, the 1930-1959 period was associated with a gradual decline in the creation of Spanish-language newspapers: New publications numbered only eighty-two. Nevertheless, Spanish-language newspapers remained stable during this period, and the total number published in any given year never fell below fortythree.

\section{Changing Immigration Patterns, Revival, and New Heights, 1960-1992}

Immigration of Spanish speakers to the United States has increased dramatically since 1960: Arrivals between 1960 and 1990 numbered more than 5.25 million. This made Spanish speakers the largest group of immigrants during the period and increased the proportion of Hispanics in the population from less than 5 percent in 1960 to nearly 1o percent in 1990 . This period was also marked by changes in the countries of origin and in the destinations of Spanish-speaking immigrants (Allen and Turner 1988). Mexican nationals still account for more than half of all Spanish- 


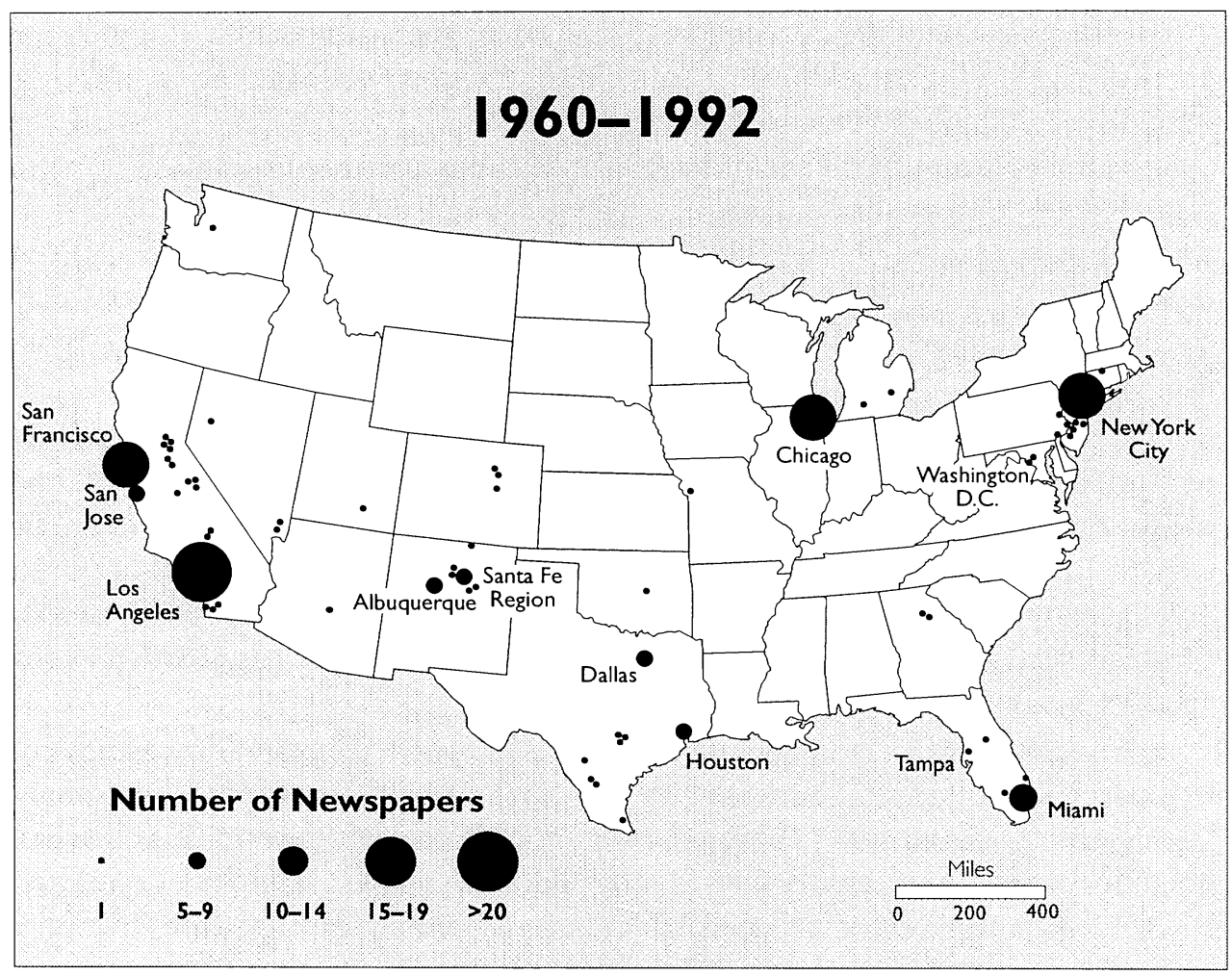

Fig. 5-Spanish-language newspapers established between 1960 and 1992. (Cartography by the Laboratory for Cartographic and Spatial Analysis, University of Akron)

speaking immigrants, but major migrations flowed from Cuba, the Dominican Republic, Guatemala, El Salvador, and other Latin American countries. Traditional migration destinations-Los Angeles and San Francisco-continued to be important, but new centers, especially in the East-Miami, New York, Chicago, and Washington, D.C.-also became consequential. These changes were mirrored in the evolving geography of the Spanish-language press (Figure 5).

Significant changes in the distribution of newly founded Spanish-language newspapers are clearly depicted in the regions west of the Mississippi. Spanishlanguage newspapers in California have continued to be established in the state's major metropolitan areas-Los Angeles, San Diego, San Jose, and San Franciscobut the founding of newspapers in the Central Valley towns of Sacramento, Stockton, Fresno, and Bakersfield mirrors the arrival of large numbers of Spanish speakers in the region since 1960. Moreover, the appearance of Spanish-language newspapers in Reno, Las Vegas, Wenatchee (Washington), Salt Lake City, Oklahoma City, and Kansas City demonstrates the increasing geographical diffusion of Spanishspeakers throughout the West. 
Decline characterizes Spanish-language newspaper publication in the some parts of the Southwest, however. Only one newspaper was founded in Arizona, none appeared in the El Paso-Las Cruces area, and only four emerged in the border cities of South Texas. At the same time, Spanish-language newspaper publishing in Texas tended to concentrate in major urban centers distant from the border-Austin, Houston, and the Dallas-Fort Worth area. Even though the establishment of newspapers in the El Paso-Las Cruces area ended, the Upper Rio Grande Valley country in the vicinity of Albuquerque and Santa Fe remained comparatively vigorous.

The most dramatic changes in Spanish-language newspaper publication occurred in the East. Chicago and New York emerged as major centers, with more than fifteen new newspapers established in them during the thirty-year period. The growth in Chicago was supported by large numbers of Mexican and Mexican American migrants and some Puerto Ricans, whereas in New York Dominican, Colombian, and other South American immigrants provided the mainstays for Spanish-language newspapers.

Spanish-language newspaper publishing also expanded beyond the confines of these urban areas into surrounding suburbs, towns, and states as Spanish-speaking immigrants achieved some degree of economic success and moved out of urban neighborhoods. For instance, newspaper publication outside New York City flourished: Newspapers were established in New Jersey, Connecticut, and even Delaware. The redistribution of Cuban and Puerto Rican populations on the eastern seaboard influenced this development. For example, New York's share of the Puerto Rican population dropped from 72 percent in 1960 to 49 percent in 1980 , with a simultaneous increase in New Jersey, Massachusetts, and Connecticut (McHugh 1989). In the Chicago metropolitan region, the spread of the Hispanic population was manifested by the publication of Spanish-language newspapers in both Lansing and Kalamazoo, Michigan. Spanish-language newspapers appeared in both Washington, D.C., and Atlanta for the first time as the dramatic economic growth of these areas provided job opportunities for recent immigrants.

Florida showed significant growth during this period, too. The growing Hispanic population in Florida, especially in the Miami metropolitan area, fostered the addition of new Spanish-language newspapers. The Miami Herald created a Spanish-language insert, El Nuevo Herald, in 1976. The insert gained so much popularity that by 1981 circulation reached 83,000 on weekdays and 94,000 for weekend editions (Veciana-Suarez 1987). El Nuevo Herald is now published as an independent newspaper and reports a weekday circulation of about 100,000. It too is accessible on the World Wide Web (http://www.elherald.com). As the Hispanic population has grown and achieved considerable economic success, it has also moved beyond Miami's city limits: Spanish-language newspapers are now published in adjacent Hialeah and Fort Lauderdale. This expansion can be seen at a statewide level as well, for Tampa, Orlando, and Immokalee each have Spanishlanguage newspapers. 


\section{CoNCLUSION}

Two patterns of Spanish-language newspaper development can be discerned in Figures 1-5, one west of the Mississippi and one east of it. The western region shows relatively steady development over the entire time span. It peaked in the early 1900 and then declined until the 1970s, at which point a lasting revitalization began. California, an exception, showed dramatic growth between 1970 and 1990. The eastern region, in contrast, did not develop until after 1940, when Hispanic migration and immigration became pronounced and created markets for Spanish-language newspapers.

In 1990 the Hispanic population of the United States reached 22.4 million, or 9 percent of the total population. The numbers of Hispanics will continue to grow, both through natural increase and through continuing immigration. A recent study projects that they may account for 21 percent of the nation's population by the year 2050 (U.S. Bureau of the Census 1993, 2). Such numbers ought to support the continuing and vigorous publication of Spanish-language newspapers in the United States well into the next century, "English-Only" movements notwithstanding. Yet that projection may be too simplistic, and Spanish-language newspaper publication in the United States may have actually peaked in the early 1990s. The recent widespread availability of almost all Latin American dailies on the World Wide Web is likely to reduce the demand for Spanish-language newspapers in educated U.S. markets. Furthermore, by 1995 many newspapers and publishing chains that had moved into Spanish-language newspaper publication, often through special editions or supplements-the Los Angeles Times, the New York Daily News, and the Fort Worth Star Telegram-had undergone serious cutbacks or ceased their efforts entirely as circulation numbers and advertising revenues failed to materialize (Myerson 1995). Spanish-language television and radio programs have continued to dominate in terms of both audience numbers and advertising dollars, and newspapers have experienced great difficulty in capturing part of those markets.

\section{FURTHER READING}

Allen, J. P., and E. J. Turner. 1988. We the People: An Atlas of America's Ethnic Diversity. New York: Macmillan.

N. W. Ayer and Sons Directory of Newspapers and Periodicals. 1933-1992. Philadelphia: N. W. Ayer and Sons.

Bean, F. D., and M. Tienda. 1987. The Hispanic Population of the United States. New York: Russell Sage Foundation.

Carlson, A. W. 1990. The Spanish-American Homeland: Four Centuries in New Mexico's Rio Arriba. Baltimore, Md.: Johns Hopkins University Press.

Editor and Publisher International Yearbook. 1959-1992. New York: E\&P Publications.

Emery, M., and E. Emery. 1988. The Press and America: An Interpretative History of the Mass Media. Englewood Cliffs, N.J.: Prentice Hall.

Fishman, J. A., ed. 1966. Language Loyalty in the United States. Rosslyn, Va.: National Clearinghouse for Bilingual Education.

Gutiérrez, F. 1977. Spanish-Language Media in America: Background, Resources, History. Journalism History 4 (2): 34-41, 65-67.

Hispanic Media and Markets. 1988-1992. Skokie, Ill.: Standard Rate and Data. 
McHugh, K. E. 1989. Hispanic Migration and Population Redistribution in the United States. Professional Geographer 41 (4): 429-439.

Miller, S. M., ed. 1987. The Ethnic Press in the United States: An Historical Analysis and Handbook. New York: Greenwood Press.

Monmonier, M. 1986. The Geography of Change in the Newspaper Industry of the Northeast United States, 1940-1980. Pennsylvania Academy of Science 60 (1): 55-59.

Myerson, A. R. 1995. Newspapers Cut Spanish-Language Publications. New York Times, 16 October, $\$ \mathrm{C}, 7$.

The 1987 Media Encyclopedia Working Press of the Nation-Newspaper Directory 1. 1986. Chicago: Automated Marketing Systsems.

Nostrand, R. L. 1992. The Hispano Homeland. Norman: University of Oklahoma Press.

Rios, H., and L. Castillo. 1970. Toward a True Chicano Bibliography-Mexican-American Newspapers 1848-1942, Part 1. El Grito, Summer, 17-24.

1972. Toward a True Chicano Bibliography-Part 2. El Grito, Summer, 40-47.

U.S. Bureau of the Census. 1993. Hispanic Americans Today. Current Population Reports, Population Characteristics, P23-183. Washington, D.C.: U.S. Department of Commerce.

Veciana-Suarez, A. 1987. Hispanic Media, USA: A Narrative Guide to Print and Electronic Hispanic News Media in the U.S. Washington, D.C.: Media Institute.

Wynar, L. R., and A. T. Wynar. 1976. Encyclopedia Directory of Ethnic Newspapers and Periodicals in the United States. $2 \mathrm{~d}$ ed. Littleton, Colo.: Libraries Unlimited. 